\title{
Brexits betydning for det vestlige Balkan
}

\section{Af Florián Bieber}

Næsten præcist et kvart århundrede efter at Slovenien og Kroatien erklærede sig uafhængige af Jugoslavien, besluttede britiske vælgere sig ved et knebent, men klart flertal at forlade den Europæiske Union.

Resultatet af den britiske folkeafstemning om UK's fortsatte tilknytning til EU satte gang i en lang proces, hvor resultatet er mere end usikkert. Meget vil afhænge af de beslutninger, der tages af britiske ledere og EU-politikere på en lang række områder, og vil være langt mere vidtrækkende end selve Brexit. Derudover vil den britiske regerings tøven med hensyn til at starte forhandlinger om udmeldelse af EU ved hjælp af Artikel 50 indebære, at UK's frigørelse fra EU vil tage minimum flere år.

Mens Europa velsagtens er i stand til at overleve denne sidste krise - fra gældskrisen over den græske krise til flygtningekrisen - vil det se meget anderledes ud end i dag, og dets evne til at lede de vestlige Balkanlande mod stabile, fremgangsrige, velstående demokratier synes at være stærkt reduceret.

Brexit-afstemningen har resulteret i betydelig usikkerhed, der gør enhver spå- dom vanskelig. Og dog er det denne usikkerhed, der vil blive Europas vigtigste kendetegn i de kommende år, og som vil influere på den politiske proces og indebære betragtelig risiko. Brexits konsekvenser er både strukturelle - EU's evne til at agere og integrere nye medlemmer, og normsættende - EU's evne til at fremme et særligt demokratisk konsensusorienteret regeringssystem.

\section{Efter Brexit}

For det første må vi tage stilling til konsekvenserne for forholdet mellem UK og EU. Vi ved, at UK som et enkeltstående land vil forlade EU i en overskuelig fremtid, men i det mindste ikke før om to år.

Hvad vi ikke ved er, om UK vil kunne overleve som et land, med Skotland, der helst vil afholde endnu en afstemning, og usikkerheden i Nordirland med hensyn til dets fremtidige forbindelse med Den Irske Republik.

Den sidste store ukendte faktor er (det amputerede) UK's forhold til EU. Tilhængere af Brexit har ikke givet en klar vision, men bare peget på Schweiz, Norge og i nogle tilfælde også Albanien og Serbien som eksempler på den fremtidi-

Florian Bieber er professor på Universitetet i Graz [Østrig] i sydøsteuropæisk historie og politik. Han var koordinator for Balkanlandene i Europe Policy Advisory Group [BiEPAG]. 
Hovedspørgsmålet er ikke, om Brexit vil ødelægge landenes tiltrædelse til EU og endnu vigtigere demokratiets tilstand i det vestlige Balkan, men hvor meget og for hvor længe

ge forbindelse med EU. Men visionen om Englands fremtidige forbindelse med EU vil ikke kun blive udformet af brexit'erne, men også af dem der tabte valget. De bliver måske afskrækket af deres tab, men de er tilstrækkeligt store i antal i det nuværende parlament og repræsenterer stadig 48 pct. af vælgerne. De vil sikkert søge stærke bånd til EU.

For det andet ved vi ikke, hvordan kædereaktionerne vil blive. EU-skepsissen har været meget udpræget i britisk politik i årtier, og det er det eneste land i EU, der tidligere har haft en afstemning om at forlade EU, dengang EC.

Men i dag står England ikke alene med sine stærke EU-skeptiske følelser, og sandheden er, at flere andre EU-medlemmer har lignende hvis ikke stærkere anti-EU-partier. For nylig blev et møde mellem meget højreorienterede EU-skeptiske partier afholdt i Østrig under mottoet ' $\mathrm{Pa}$ triotisk Forår.' Der er ingen tvivl om, at det allerede stærke yderste højre vil kræve deres eget valg, som den hollandske ultra-højreorienterede politiker Geert Wilders allerede har forlangt som kommentar til Brexit-afstemningen.

Denne anmodnings succes afhænger af, hvor attraktiv en udmelding bliver for England. Hvis det lykkes for England at udmelde sig på lempelige vilkår, vil det opmuntre andre til at følge efter. Hvis det mislykkes, vil det afholde vælgerne i andre lande fra at kræve afstemning. Her skal en vigtig advarselslampe lyse. Hvis årsagen til briternes kamp, hvad nogle mener, er et ubøjeligt og straffende EU, vil det kun styrke anti-EU fortællingen hos populistiske partier.
For det tredje ser det europæiske integrationsprojekt skrammet ud efter Brexit. Selv uden EU-skeptiske forlangender vil spørgsmålet om EU's videre kurs efter afstemningen tårne sig faretruende op i horisonten over størstedelen af unionen. Selvom det ser ud som om afstemningen har mindre med EU at gøre og mere med immigration, er der ingen tvivl om, at den afmægtige varetagelse af flygtningene i Europa i de senere år har medvirket til opfattelsen af EU som inkompetent.

Blandt de 27 tilbageblevne medlemsstater har ingen mod på mere integration. På samme tid synes status quo at være grunden til krisen, og at overgive mere magt til medlemsstaterne vil kun tilfredsstille skeptikerne og sikkert udløse mere forvirring og konfusion, hvilket har bragt EU derhen, hvor det er i dag. At skulle løse cirklens kvadratur ved på den ene side at imødekomme kravene om et mindre magtfuldt EU, og på den anden side sikre et mere effektivt EU vil blive et vigtigt og overvældende tema blandt de tilbageblevne 27 .

For det fjerde vil det britiske parlaments interesse $i$ at bevare nogle forbindelsesled til EU intensivere diskussionerne om en ydre ring af EU-tilknytning. Mens Schweiz, Island, Liechtenstein og Norge allerede nyder sådan et partnerskab gennem det Europæiske Økonomiske Samarbejdsområde og bilaterale aftaler, kan UK's overgang til denne gruppe måske få denne gruppe til at vejre morgenluft og håbe på et muligt mellemstadium til et medlemskab af EU.

Udvidelsen af denne ydre ring kunne udvikle sig til et alternativ eller i det 
mindste en mellemstation til medlemskab for lande der søger optagelse i EU, inklusive de vestlige Balkanlande.

Endelig vil EU's mulighed for at agere uden for sine grænser blive meget reducerede. England har været vigtig, når det kom til at projicere EU's magt, herunder at besætte ét af EU's to sæder i FN's Sikkerhedsråd.

Brexit-afstemningen berøver ikke blot EU et af sine nøglemedlemmer, men giver det også et ry internationalt som et 'ramponeret' projekt. Således vil den transformative kraft, der ofte tilskrives EU, i det mindste i dets umiddelbare nærhed, lide. Intet sted vil den formindskede magt i EU være mere synlig end i den region, som har et ønske om at blive medlem af EU i en overskuelig fremtid: Balkans vestlige lande.

\section{Konstant krise}

Følgevirkningerne af Brexit-afstemningen er for Balkan uendeligt negative.

Hovedspørgsmålet er ikke, om Brexit vil ødelægge landenes tiltræedelse til EU og endnu vigtigere demokratiets tilstand i det vestlige Balkan, men hvor meget og for hvor længe. I de sidste mange år har EU eksporteret ustabilitet til Balkan. Den inkompetente varetagelse af flygtningene og nu Brexit udløser usikkerhed og pres på lande i EU's periferi, der savner det samme niveau af institutionelle sikkerhedsforanstaltninger, økonomiske midler og ressourcer til at modstå disse kriser.

At det vestlige Balkan har været i en konstant krisesituation igennem de sidste fire årtier, afbrudt af en kort periode af normalitet, kunne måske gøre landene mere smidige over for ydre chok, men også føre til en region, der er skrøbelig, og som har let ved at blive rendt over ende.
Gennem en årrække har processen om medlemskab af EU været drivkraften for en politisk og økonomisk reform for Balkans vestlige lande. Denne drivkraft er blevet svækket i de senere år med de forskellige kriser i EU, der efterhånden har mistet sin attraktion for landene, og EU har sat udvidelse på vågeblus.

Udvidelsen er dog fortsat, og Serbien og Montenegro er i forhandling, Albanien er kandidat, ligeså Makedonien dog med et spørgsmålstegn på grund af de politiske kriser gennem de senere år. Bosnien og Hercegovina har forelagt deres ansøgning om EU-medlemskab for bare et par måneder siden, og Kosovo forbliver længst væk, men underskrev en Stabiliserings- og Samarbejdsaftale for nylig.

Denne tekniske proces har mistet meget af sin politiske opbakning i EU, og regeringerne på Balkan synes ofte uvillige til at indføre reformer der er nødvendige for medlemskab. Således har alle landene på Balkan oplevet en indskrænkning af demokratiet og borgerrettighederne i de senere år.

Med Englands farvel til EU har Balkans vestlige lande mistet deres vigtigste fortaler for udvidelse. Mens mange lande var blevet kritiske over for udvidelse, har UK været det land, der ivrigt både talte for udvidelse og reformer i regionen. Sammen med Tyskland har det været det eneste store EU-land der har forsøgt at planlægge en EU-politik over for det vestlige Balkan i de sidste ti år. Nu vil denne fortaler for udvidelse forsvinde fra EU-medlemmernes rækker.

Selvfølgelig vil UK være i stand til at opmuntre til reformer og EU-medlemskab fra sidelinjen. På en måde der ligner USA's, som har støttet EU-udvidelse og i det store og hele bakket op om EU's 
politik i regionen. Men UK's troværdighed vil blive stærkt decimeret som argument til at søge medlemskab i EU, efter at de selv har ophævet forbindelsen og vil fremstå som et ekstremt tilfælde af 'gør som jeg siger, men ikke som jeg gør'.

Dernæst vil det blive en herkulisk opgave at få fastlagt forholdet mellem England og EU, ikke bare for UK, men også for unionen. Således vil ikke kun al politisk opmærksomhed, men også hele EU's embedsværk i de kommende år, være fokuseret på at håndtere forholdet. Hvad karakteren af forhold end bliver, er der mange forhandlinger, der skal gennemføres, og det vil kræve hele EU's opmærksomhed.

Udvidelsen og reformprocessen i det vestlige Balkan vil dermed blot blive et gøglertelt i forhold til det store teater og irrelevant og marginaliseret (fra et EU-perspektiv).

I tilfælde af at UK går i opløsning på grund af Skotlands ønske om at forblive i EU skal vanskelige spørgsmål nødvendigvis løses med hensyn til hvordan og hvis Skotland kan forblive uden at 'slutte sig' til EU igen. Igen vil dette endnu engang komplicere ophævelsen af UK's forbindelse med EU og beskæftige politikerne og embedsmændene i Bruxelles og EU-hovedstæder i de kommende år.

For det tredje, hvis EU er i en eksistentiel krise, hvad skal det så nytte at blive ved med at søge medlemskab? Især for eliten, hvis forpligtelse over for reformer er tvivlsom. EU-medlemskab har stået øverst på dagsordenen på grund af belønninger fra vestlige regeringer, og fordi et stort antal vælgere forlangte det. Men denne kalkulation kan meget vel skifte og fjerne sig endnu længere fra både integration og reformer med hensyn til EU, hvilket det allerede har gjort i de senere år.
Mens indflydelsen fra Rusland og Tyrkiet i det vestlige Balkan ofte er overdrevet, fremstår disse landes regeringsmodeller attraktive for mange regionale ledere, der derfor meget vel kunne tænkes at bringe deres førte politik i overensstemmelse med disse frem for andre ikke-EU-medlemmers.

Topmødet i juli 2016 i Paris angående det vestlige Balkan bekræftede det vestlige Balkans ønske om medlemskab i EU og fastholdelsen af et 'europæisk perspektiv'. Ligeledes har Europa-Kommission fortsat udvidelsesprocessen lige siden og søgt at forsikre regionen om, at uanset den større politiske omvæltning så fortsætter optagelsesprocessen.

Men der er også mindre opmuntrende signaler. Den årlige tale om 'Unionens tilstand' af præsident Juncker i september 2016 nævnte ikke udvidelsen med et ord. Ligeledes nævnte Bratislava-topmødet, der var det første til at fremlægge en agenda for EU efter Brexit-afstemningen den samme måned ikke udvidelsen med et ord og fokuserede i stedet på sikkerhed, grænser og økonomisk udvikling.

Her tre måneder efter Brexit-afstemningen kan implikationerne af afstemningen for Balkanlandene derfor ikke til fulde forudses, især da vi i dag er lige i begyndelsen af processen. Baseret på tre scenarier vil vi skitsere nogle af Brexit-processens muligheder for det vestlige Balkan.

\section{UK og Europa splittes}

Det første scenario forudsætter, at England opløses, i det mindste med hensyn til Skotlands udmeldelse, men med et muligt valg i Nordirland og i andre EU-lande. Nogle afstemninger vil lykkes, men ikke alle. Skotland vil sikkert ikke være i stand til at forblive i EU, men bliver nødt 
til at genforhandle medlemskabets betingelser parallelt med, at UK forlader EU. De forbitrede og vanskelige forhandlinger vil føre til forværrelse af relationerne mellem EU og UK.

På samme tid vil den skotske afstemning opmuntre til endnu en afstemning i Catalonien og andre steder. Med hele opmærksomheden henvendt på UK og det fremtidige forhold, vil EU's evne til at løse andre kriser, indbefattet Grækenland og flygtningespørgsmålet. være yderst begrænset.

I sådan et scenario kunne det tænkes, at EU må se sig reduceret, og der opstår et kerne-EU med mangfoldige integrationslag på forskellige planer. For det vestlige Balkan vil EU's transformative drivkraft forsvinde, og ligefrem forkastelse af EU og lignende reformer kunne forekomme. Ydermere kunne løsrivelsesbevægelserne i regionen, såsom i republikken Srpska, opmuntres af den større europæiske drivkraft og få det meste ud af situationen.

Både UK og EU har en stærk interesse $i$ at afværge dette scenario og Parlamentets tøvende tilnærmelse til Brexit antyder en velovervejet indsats for at undgå en indenrigspolitisk krise i Skotland og Nordirland, men evnen til at overtale begge regioner til at forblive i UK vil afhænge af forhandlingerne med EU og er derfor usikker.

\section{UK splittes, Europa forenes}

Ifølge dette scenario vil England træde ud, og Skotland vil forblive i EU og således skabe et tilbageslag for Brexit, da prisen for beslutningen synes at blive meget høj.

Dette vil lette en aftale, der gør England, Wales og Nordirland til medlemmer af det Europæiske Økonomiske Samarbejdsområde med åben grænse til
Skotland og Irland. Faktisk ville EU være i stand til at operere videre, da den britiske erfaring vil afskrække andre afstemninger om udtrædelse af EU - eller føre til nederlag hvis de gennemføres.

Efter en periode med vanskeligheder vil EU være i stand til at genoptage udvidelserne, dog vil UK's udtrædelse og afskeden med England, Wales og Nordirland resultere i et stærkere tysk overherredømme i EU.

EU-medlemskab for det vestlige Balkan kunne genoplives som en levedygtig mulighed efter kriseårene, og med Det Europæiske Økonomiske Samarbejdsområde eller en lignende mellemstation til EU kunne landene i det vestlige Balkan få muligheden for et hurtigere skridt til fuldt medlemskab. Der er dog en risiko for, at en løsere form for integration kan opstå, ikke som en mellemstation mod fuldt medlemskab men som en mere permanent og endegyldig form for integration.

\section{UK forenes, Europa splittes}

Mens en skotsk afstemning i kølvandet på Brexit er en mulighed, kan UK's håndtering af dets fremtidige relationer med $\mathrm{EU}$ i stor udstrækning forme fremtiden for UK og sikre dets overlevelse.

Hvis UK definerer en forhandlingssituation, der reflekterer landets opdeling og søger at bevare 'mini'-medlemskab, kunne Skotland blive formildet, og landet ville overleve. EU-ledere vil sandsynligvis ikke kunne lide eller acceptere sådanne planer, da de kunne frygte, at det at lade England både blæse og have mel i munden, kun ville opmuntre andre.

Imidlertid ville EU måske acceptere sådan et scenario for at afværge for megen bitterhed. Som konsekvens kunne UK forblive en vigtig international spiller, om 
end svækket. Her ville UK forblive nært knyttet til EU uden et fuldt medlemskab, men tilstrækkeligt til at beholde Skotland og Nordirland som en del af UK. For det vestlige Balkan ville sådan et scenario være det tættest mulige til status quo, men selv her ville drivkraften til medlemskab og reformer være stærkt reduceret.

\section{Risikoen for Balkan}

De tre scenarier sætter spot på den anseelige risiko, Brexit udgør for det vestlige Balkans lande. Med EU's fokus alle andre steder i de kommende år, selvoptaget og svækket, kan lande ikke mere stole på EU's evne til at understøtte reformer og konsolidere demokratier. Med EU's transformative tiltrækning i det store og hele borte, og dets mulighed for at agere formindsket, vil andre udfylde tomrummet (det inkluderer individuelle EU-medlemslande).

I den korte eller mellemliggende periode synes dette tydeligt at opmuntre halvautoritære ledere, som er villige redskaber for den højest bydende - det være sig Tyrkiet, Rusland, Kina eller andre magter eller investorer.

Desuden ser et mere sikkerhedsorienteret EU, der søger at afværge flygtningestrømme og bekymrer sig om terrorisme, det vestlige Balkan mere som samarbejdspartnere, der kan opbygge sikre grænseovergange, end som demokratiske partnere inden for EU.

Således kan det vestlige Balkan blive sikkerhedsvagter for den sårbare sydøstlige grænse, men uden for EU. Socia- le bevægelser, medier og uafhængige institutioner vil have færre ydre allierede at stole på. Dette kunne forstærke de nationale bevægelser for forandring, men det kan også afkøle dem, hvis de trendsættende idoler bliver færre eller er forsvundet.

For at stoppe denne negative tendens, må et antal EU-medlemmer, især Tyskland, men også USA danne koalitioner for forandring i det vestlige Balkan. Bortset fra risikoen for væbnet konflikt har det vestlige Balkan lav prioritet, men den snigende fremmarch af autoritære principper er ikke blot en fare for regionen, men del af en alvorligere europæisk feber, der ikke kan ignoreres længere.

Brexit-afstemningen er også del af en voksende bølge af populisme og nationalisme i Europa og Nordamerika. Derfor er det vigtigt, at Brexit også forstås som en del af denne større tendens, der påvirker både EU og det vestlige Balkan.

Mens disse bevægelsers succes, bortset fra Brexit, ikke er tydelig, sætter de skarpt lys på en krise for de etablerede partier og konsensusbaserede liberale europæiske demokratier, som sikkert vil indebære alvorligere konsekvenser for det vestlige Balkan, både ved at underminere svage hjemlige institutioner og ved at berøve dem et ideal og en ven i EU.

Således kunne Brexit godt være blot en forløber for kommende udfordringer.

Oversat fra engelsk af Christiane Rohde 